\title{
DÜBLIN
}

Technological University Dublin

ARROW@TU Dublin

Articles

School of Chemical and Pharmaceutical

Sciences

2017

\section{An Ionic Liquid Based Sensor for Diclofenac Determination in Water}

\author{
Emma Brennan \\ Technological University Dublin \\ Pauline Futvoie \\ Haute Ecole Leonard de Vinci, Woluwe-Saint Lambert, Belgium \\ John Cassidy \\ Technological University Dublin, john.cassidy@tudublin.ie
}

See next page for additional authors

Follow this and additional works at: https://arrow.tudublin.ie/scschcpsart

Part of the Chemistry Commons

\section{Recommended Citation}

Brennan, E., Futvoie, P., Cassidy, J. \& Schazmann, B. (2017). An ionic liquid based sensor for diclofenac determination in water.International Journal of Environmental Analytical Chemistry, 97(6),pp. 588-596. doi:10.1080/03067319.2017.1333607

This Article is brought to you for free and open access by the School of Chemical and Pharmaceutical Sciences at ARROW@TU Dublin. It has been accepted for inclusion in Articles by an authorized administrator of ARROW@TU Dublin. For more information, please contact arrow.admin@tudublin.ie, aisling.coyne@tudublin.ie, gerard.connolly@tudublin.ie.

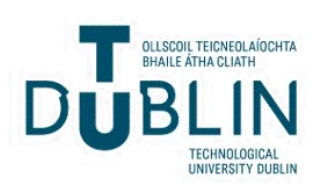




\section{Authors}

Emma Brennan, Pauline Futvoie, John Cassidy, and Benjamin Schazmann

This article is available at ARROW@TU Dublin: https://arrow.tudublin.ie/scschcpsart/82 
Journal acronym: GEAC

Author(s): $\quad$ Emma Brennan, Pauline Futvoie, John Cassidy and Benjamin Schazmann

Article title: An ionic liquid-based sensor for diclofenac determination in water

Article no: $\quad 1333607$

Enclosures: $\quad$ 1) Query sheet

2) Article proofs

Dear Author,

1. Please check these proofs carefully. It is the responsibility of the corresponding author to check these and approve or amend them. A second proof is not normally provided. Taylor \& Francis cannot be held responsible for uncorrected errors, even if introduced during the production process. Once your corrections have been added to the article, it will be considered ready for publication.

Please limit changes at this stage to the correction of errors. You should not make trivial changes, improve prose style, add new material, or delete existing material at this stage. You may be charged if your corrections are excessive (we would not expect corrections to exceed 30 changes).

For detailed guidance on how to check your proofs, please paste this address into a new browser window: http://journalauthors.tandf.co.uk/production/checkingproofs.asp

Your PDF proof file has been enabled so that you can comment on the proof directly using Adobe Acrobat. If you wish to do this, please save the file to your hard disk first. For further information on marking corrections using Acrobat, please paste this address into a new browser window: http://journalauthors.tandf.co.uk/production/acrobat.asp

2. Please review the table of contributors below and confirm that the first and last names are structured correctly and that the authors are listed in the correct order of contribution. This check is to ensure that your name will appear correctly online and when the article is indexed.

\begin{tabular}{|l|l|l|l|l|}
\hline Sequence & Prefix & Given name(s) & Surname & Suffix \\
\hline 1 & & Emma & Brennan & \\
\hline 2 & & Pauline & Futvoie & \\
\hline 3 & & John & Cassidy & \\
\hline 4 & & Benjamin & Schazmann & \\
\hline
\end{tabular}


Queries are marked in the margins of the proofs, and you can also click the hyperlinks below.

Content changes made during copy-editing are shown as tracked changes. Inserted text is in red font and revisions have a red indicator $\curlywedge$. Changes can also be viewed using the list comments function. To correct the proofs, you should insert or delete text following the instructions below, but do not add comments to the existing tracked changes.

\section{General points:}

\section{AUTHOR QUERIES}

1. Permissions: You have warranted that you have secured the necessary written permission from the appropriate copyright owner for the reproduction of any text, illustration, or other material in your article. Please see http://journalauthors.tandf.co.uk/permissions/usingThirdPartyMaterial.asp.

2. Third-party content: If there is third-party content in your article, please check that the rightsholder details for re-use are shown correctly.

3. Affiliation: The corresponding author is responsible for ensuring that address and email details are correct for all the co-authors. Affiliations given in the article should be the affiliation at the time the research was conducted. Please see http://journalauthors.tandf.co.uk/preparation/writing.asp.

4. Funding: Was your research for this article funded by a funding agency? If so, please insert 'This work was supported by <insert the name of the funding agency in full>', followed by the grant number in square brackets '[grant number xxxx]'.

5. Supplemental data and underlying research materials: Do you wish to include the location of the underlying research materials (e.g. data, samples or models) for your article? If so, please insert this sentence before the reference section: 'The underlying research materials for this article can be accessed at $<$ full link> / description of location [author to complete]'. If your article includes supplemental data, the link will also be provided in this paragraph. See <http://journalauthors.tandf.co.uk/preparation/multimedia.asp $>$ for further explanation of supplemental data and underlying research materials.

6. The CrossRef database (www.crossref.org/) has been used to validate the references. Changes resulting from mismatches are tracked in red font.

AQ1 Please provide missing department name for affiliations " $a$ and b".

AQ2 Please spell out "PVC" in full at first mention.

AQ3 Please spell out "NMR" in full at first mention.

AQ4 Please spell out "NPOE" and "THF" in full at first mention.

AQ5 Please spell out "IL" in full at first mention.

AQ6 Please note that as per journal style funding info in the acknowledgements should be additionally included in a separate funding section. As per this style, we have additionally included the funding info in a separate funding section, also retaining the funding info in the acknowledgements section. Please check 
both the acknowledgements and the funding sections and confirm that they are correct.

AQ7 The disclosure statement has been inserted. Please correct if this is inaccurate.

AQ8 The CrossRef database (www.crossref.org/) has been used to validate the references. Mismatches between the original manuscript and CrossRef are tracked in red font. Please provide a revision if the change is incorrect. Do not comment on correct changes.

AQ9 Please provide missing page number for Ref. [22].

AQ10 Please mention Figure 1 in the text.

AQ11 Please mention Figure 3 in the text. 


\section{How to make corrections to your proofs using Adobe Acrobat/Reader}

Taylor \& Francis offers you a choice of options to help you make corrections to your proofs. Your PDF proof file has been enabled so that you can mark up the proof directly using Adobe Acrobat/Reader. This is the simplest and best way for you to ensure that your corrections will be incorporated. If you wish to do this, please follow these instructions:

1. Save the file to your hard disk.

2. Check which version of Adobe Acrobat/Reader you have on your computer. You can do this by clicking on the "Help" tab, and then "About".

If Adobe Reader is not installed, you can get the latest version free from http://get. adobe.com/reader/.

3. If you have Adobe Acrobat/Reader 10 or a later version, click on the "Comment" link at the right-hand side to view the Comments pane.

4. You can then select any text and mark it up for deletion or replacement, or insert new text as needed. Please note that these will clearly be displayed in the Comments pane and secondary annotation is not needed to draw attention to your corrections. If you need to include new sections of text, it is also possible to add a comment to the proofs. To do this, use the Sticky Note tool in the task bar. Please also see our FAQs here: http://journalauthors.tandf.co.uk/production/index.asp.

5. Make sure that you save the file when you close the document before uploading it to CATS using the "Upload File" button on the online correction form. If you have more than one file, please zip them together and then upload the zip file.

If you prefer, you can make your corrections using the CATS online correction form.

\section{Troubleshooting}

Acrobat help: http://helpx.adobe.com/acrobat.html

Reader help: http://helpx.adobe.com/reader.html

Please note that full user guides for earlier versions of these programs are available from the Adobe Help pages by clicking on the link "Previous versions" under the "Help and tutorials" heading from the relevant link above. Commenting functionality is available from Adobe Reader 8.0 onwards and from Adobe Acrobat 7.0 onwards.

Firefox users: Firefox's inbuilt PDF Viewer is set to the default; please see the following for instructions on how to use this and download the PDF to your hard drive: http://support.mozilla.org/en-US/kb/view-pdf-files-firefox-without-downloadingthem\#w_using-a-pdf-reader-plugin 


\title{
An ionic liquid/-based sensor for diclofenac determination in water
}

\author{
Emma Brennan ${ }^{\mathrm{a}}$, Pauline Futvoie ${ }^{\mathrm{b}}$, John Cassidy a and Benjamin Schazmann ${ }^{\mathrm{a}}$
}

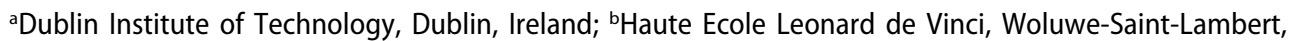
Belgium

\begin{abstract}
This paper details a miniaturised, solid state ion-selective electrode selective for diclofenac. The sensor comprises a novel ionic liquid electroactive material - an imidazolium-diclofenac ion associate. The ion associate is present in a plasticised PVC membrane on planar carbon electrodes, with an intermediate poly (3,4-ethylenedioxythiophene) layer. The sensitivity and selectivity of the sensor were determined using chronopotentiometric methods. In response to diclofenac, a slope of $-53.3 \pm 3.6 \mathrm{mV} /$ dec was observed. A limit of detection of $2.90 \times 10^{-3} \mathrm{~g} \mathrm{~L}^{-1}$ is reported, with a linear range of $3.18 \times 10^{-3} \mathrm{~g} \mathrm{~L}^{-1}$ to $3.18 \mathrm{~g} \mathrm{~L}^{-1}$. The sensors show good selectivity towards diclofenac against pertinent interferent molecules, with a response time of $<15 \mathrm{~s}$.
\end{abstract}

\section{ARTICLE HISTORY}

Received 3 October 2016

Accepted 15 May 2017

\section{KEYWORDS}

Sensor; potentiometric; diclofenac; ISE;

environmental; ionic liquid

\section{Introduction}

Diclofenac is an analgesic with both human and veterinary applications. It has been described as an emerging contaminant $[1,2]$ due to its activity as an endocrine disruptor even at low environmental concentrations, it affects the endocrine system of biological species. It has been banned for veterinary use in India due to links with declining vulture populations across the Indian subcontinent $[3,4]$. As such, improved analytical methods for its determination are essential for continuous environmental monitoring.

Where diclofenac has a carboxylate group in its structure, it is supplied and administered as its sodium salt. This enables a higher degree of ionisation, and thus dissociation, at biological $\mathrm{pH}$. The ionic nature of the drug makes it ideal for quantification by ionselective electrode (ISE).

ISEs are frequently used for environmental analysis, most commonly for $\mathrm{pH}$, fluoride and nitrate. This type of electrode is selective for a target ion, ideally with minimal interference from others, and works by transducing analyte activity into electrical potential. They are typically used for quantitative analysis. Previously, we have developed ISEs for environmental ions nitrate and mercury $[5,6]$.

Traditionally, ISEs are made of glass or plastiç and contain an inner filling solution, with a selective membrane separating it from the sample solution. It is across this 


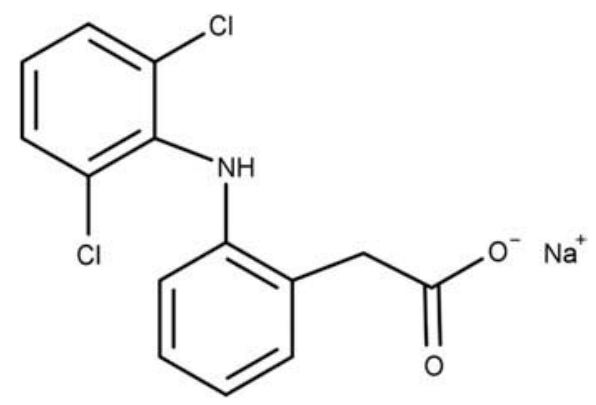

Figure 1. Diclofenac sodium.

membrane that a potential is created, correlating to analyte activity in the sample. More recently, all solid, state ISEs have been developed, which require no filling solution and as such are more robust. Solid state sensors are also compact - they can be any size as determined by the electrode area, making them ideal for field analysis applications [7-9].

Diclofenac-selective sensors have been investigated in the past, most commonly employing the traditional 'wet' ISE format. Kormosh _et al. have developed ion associates of diclofenac and base dyes for use as sensing material in this classical sensor format [10-12]. A solid state, diclofenac-selective ISE is proposed in this paper. This type of ISE has been reported by several authors, such as polypyrrole- [13] and porphyrin-based [14] jelectrodes.

A novel associate of diclofenac with an imidazolium moiety, [bpim][dfc] (Figure 2), is proposed to act as diclofenac-selective material and ion exchanger in a solid contact carbon-based ISE. The associate is a room temperature ionic liquid - a salt which is molten at room temperature. lonic liquids are conductive and have many applications, including as electrolytic solution [15] in batteries and solvents. They have been shown as effective electroactive materials in sensors [16-18].

The conducting polymer poly(34-ethylenedioxythiophene) (PEDOT) is applied as an intermediate layer, between membrane and carbon ink, acting as ion-to-electron transducer and negating the requirement for filling solution [19].

\section{Experimental}

\subsection{Materials and apparatus}

All materials procured from Sigma-Aldrich Ireland and used without further purification. A Lawson EMF-16 was used as potentiometer, with an Orion 900200 double junction

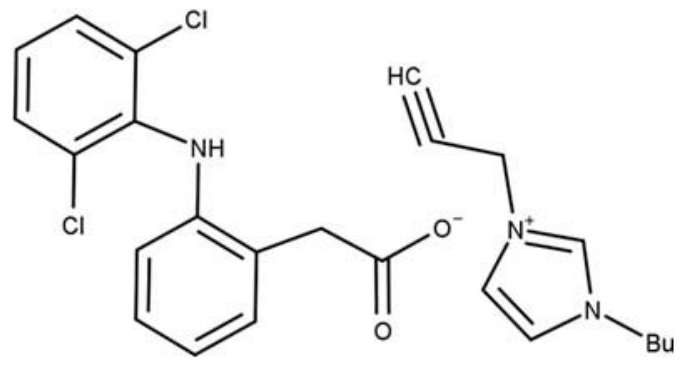

Figure 2. [bpim][dfc] structure. 


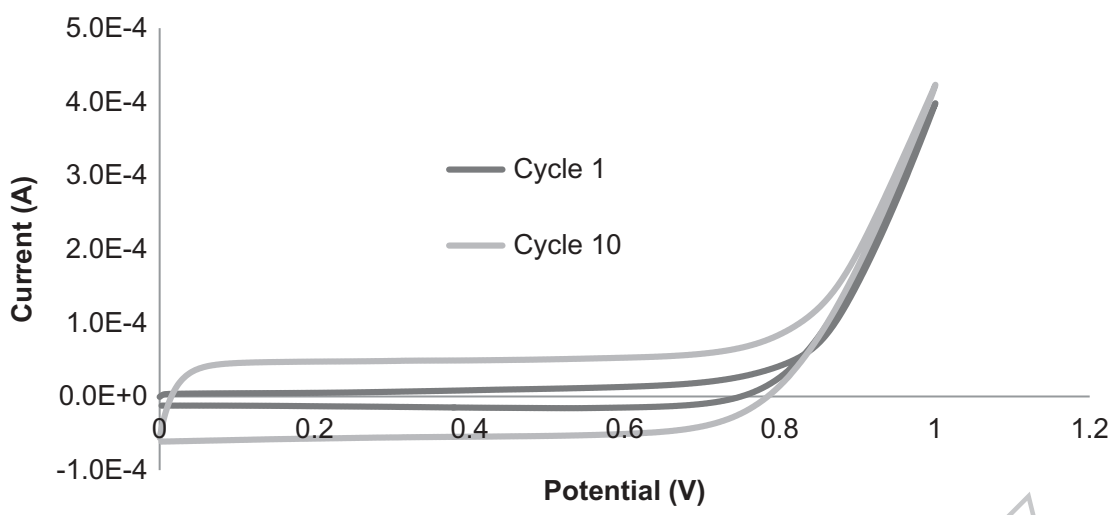

Figure 3. Cyclic voltammograms depicting PEDOT electropolymerisation. The rising current with cycle number indicates formation of the electroactive layer on the electrode surface.

reference electrode. An Autolab PGSTAT12 potentiostat was used for cyclic voltammetry. ERCON E31078 as carbon ink and Electrodag 452SS as dielectric ink were used to fabricate screen-printed carbon electrodes, using a DEK 248 semi-automatic screen printer to print carbon 'lollipop' tracks. Ultrapure Milli-Q water $\left(14.0 \mathrm{M} \Omega \mathrm{cm}^{-1}\right)$ was used for all experiments and solutions. A Bruker Avance $400 \mathrm{MHz}$ NMR was used to obtain spectra.

\subsection{Preparation of [bpim][dfc]}

Butyl imidazole $(3.7255 \mathrm{~g}, 30 \mathrm{mmol})$ was chilled on ice for $5 \mathrm{~min}$. Propargyl bromide solution $\left(3.9450 \mathrm{~cm}^{3}, 35 \mathrm{mmol}\right)$ was added dropwise under nitrogen and stirred for $10 \mathrm{~min}$.

The mixture was brought to $70^{\circ} \mathrm{C}$ and stirred for $10 \mathrm{~min}$, then stirred at room temperature for 14 h 1 under nitrogen. The resulting amber, viscous fluid was dried by rotary evaporation to yield the ionic liquid 1-butyl-3-propargyl imidazolium bromide (6.1920 g, 86\% yield). ${ }^{1} \mathrm{H}-\mathrm{NMR}$ : $\delta / \mathrm{ppm}(400 \mathrm{MHz}, \mathrm{d}-\mathrm{DMSO})=9.55(\mathrm{~s}, 1 \mathrm{H}), 7.98(\mathrm{t}, 1 \mathrm{H}$, $\mathrm{J}=1.8), 7.89(\mathrm{t}, 1 \mathrm{H}, \mathrm{J}=1.8), 5.32(\mathrm{~d}, 2 \mathrm{H}, \mathrm{J}=2.6), 4.26(\mathrm{t}, 2 \mathrm{H}, \mathrm{J}=7.2), 3.86(\mathrm{t}, 1 \mathrm{H}, \mathrm{J}=2.6)$, $1.75(\mathrm{~m}, 2 \mathrm{H}), 1.22(\mathrm{~m}, 2 \mathrm{H}), 0.84(\mathrm{~m}, 3 \mathrm{H}) .{ }^{13} \mathrm{C}-\mathrm{NMR}: \delta / \mathrm{ppm}(400 \mathrm{MHz}, \mathrm{d}-\mathrm{DMSO})=136.0$, $122.8,122.2,78.9,75.9,48.7,38.6,31.4,18.7,13.2$.

Aqueous solution of diclofenac sodium $\left(10 \mathrm{mmol}\right.$ in $\left.65.0 \mathrm{~cm}^{3}\right)$ was added dropwise to a solution of aqueous 1-butyl-3-propargyl imidazolium bromide $(3 \mathrm{mmol}$ in $\left.6.0 \mathrm{~cm}^{3}\right)$ and stirred for $4 \mathrm{~h}$. This was extracted with diethyl ether/ethyl acetate and dried under vacuum. The resulting brown oil was oven dried at $80^{\circ} \mathrm{C}$ for $4 \mathrm{~h}$. The complex $(520 \mathrm{mg}$ ) was dark brown in colour, with a sticky, tar-like consistency and $37 \%$ yield.

${ }^{1} \mathrm{H}-\mathrm{NMR}$ (400 MHz, d-DMSO) $\delta / p p m: 9.91(\mathrm{~s}, 1 \mathrm{H}), 9.78(\mathrm{~s}, 1 \mathrm{H}), 7.70(\mathrm{dt}, 2 \mathrm{H}, \mathrm{J}=5.8,1.8)$, $7.38(\mathrm{~d}, 2 \mathrm{H}, \mathrm{J}=8.0), 7.18(\mathrm{~d}, 1 \mathrm{H}, \mathrm{J}=7.4), 7.04(\mathrm{t}, 1 \mathrm{H}, \mathrm{J}=8.1), 6.96(\mathrm{t}, 1 \mathrm{H}, \mathrm{J}=7.6), 6.76(\mathrm{t}$, $1 \mathrm{H}, \mathrm{J}=7.4), 6.39(\mathrm{~d}, 1 \mathrm{H}, \mathrm{J}=7.9), 5.33(\mathrm{~d}, 2 \mathrm{H}, \mathrm{J}=2.6), 4.23(\mathrm{t}, 2 \mathrm{H}, \mathrm{J}=4.2), 3.60(\mathrm{~s}, 2 \mathrm{H}), 3.32$ $(\mathrm{t}, 1 \mathrm{H}, \mathrm{J}=2.6), 1.77(\mathrm{~m}, 2 \mathrm{H}), 1.21(\mathrm{~m}, 2 \mathrm{H}), 0.84(\mathrm{t}, 3 \mathrm{H}, \mathrm{J}=7.6) .{ }^{13} \mathrm{C}-N M R: 178.2,143.2,138.4$, $129.5,128.8,127.0,126.3,123.1,122.6,122.0,121.3,120.9,120.6,116.7,98.1,90.2,74.8$, $49.7,43.4,39.1,31.9,31.0,19.4,13.4$. 


\subsection{Preparation of electrodes}

\subsubsection{PEDOT coating}

To a potentiostat, two electrodes were connected in tandem, with a saturated calomel reference electrode and graphite auxiliary electrode. The electrodes were immersed in a mixed solution of EDOT $(0.01 \mathrm{M})$ and $\mathrm{KNO}_{3}(0.1 \mathrm{M})$, with stirring. At $50 \mathrm{mV} \mathrm{s}^{-1}$ scan rate, the cell was cycled from 0 to $1.2 \mathrm{~V}$, for a total of 20 scans.

\subsubsection{Membrane formulation}

AQ4 [bpim][dfc] (6.4 mg), PVC (125 mg) and NPOE (250 mg) were dissolved in THF $\left(\sim 2 \mathrm{~cm}^{3}\right)$, until a homogenous, viscous mixture was obtained. This was dropcasted in $\mu \mathrm{L}$ quantities onto PEDOT-coated electrodes.

\subsection{Electrode function}

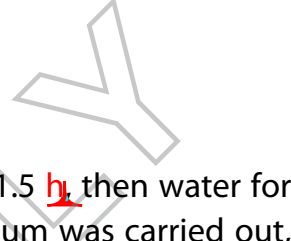

The electrodes were conditioned in diclofenac solution $\left(10^{-4} \mathrm{M}\right)$ for 1.5 h, then water for
30 min, prior to testing. Potentiometric titration with diclofenac sodium was carried out, and selectivity was determined using the separate solutions method (SSM). Potentiometric response to chloride, fluoride, sulphate, bromide, acetate, nitrate, salicylate, ibuprofen and aspirin was examined. The electrodes were also alternated between 3.18 and $3.18 \times 10_{\curlywedge}^{-2} \mathrm{~g} \mathrm{~L}^{-1}$ diclofenac solutions to determine signal reversibility.

A standard addition method was employed for sample evaluation, where aliquots of diclofenac sodium standard were added to sample solutions.

\section{Results and discussion}

\subsection{Membrane composition}

The structure of the ion associate was verified by ${ }^{1} \mathrm{H}$ - and ${ }^{13} \mathrm{C}-\mathrm{NMR}$. Deviation in chemical shift relative to starting materials is indicative of associate formation, and peak integrations are evidential of a 1:1 complex. The complex is dark brown in colour, with a thick gel-like consistency. It is sparingly soluble in waten and soluble in tetrahydrofuran and ethyl acetate. The relative insolubility of the complex in water is ideal for analysis in aqueous matrices (i.e._environmental and biological samples), as the integrity of the membrane is most likely to remain intact. Four identical electrodes were tested regularly over a 2 -month period with no evidence of electrode deterioration (or leaching) observed. The [bpim][dfc] complex acts as ion exchanger in the membrane, negating the requirement for an additional ion exchanger - a fundamental component of many ISEs, that can be costly. This means a simpler electrode configuration.

NPOE was chosen for formulation to decrease resistance and lipophilicity of the PVC membrane. As diclofenac is similarly lipophilic, migration of the analyte to the membrane is further promoted, with suppression of interferent signals from hydrophilic anions.

\subsection{Response to diclofenac}

The sensors $(n=4)$ exhibit a linear response to diclofenac, at concentrations above $\log a \geq-5$ (Figure 4). The slope of the calibration curve is sufficiently Nernstian, at 


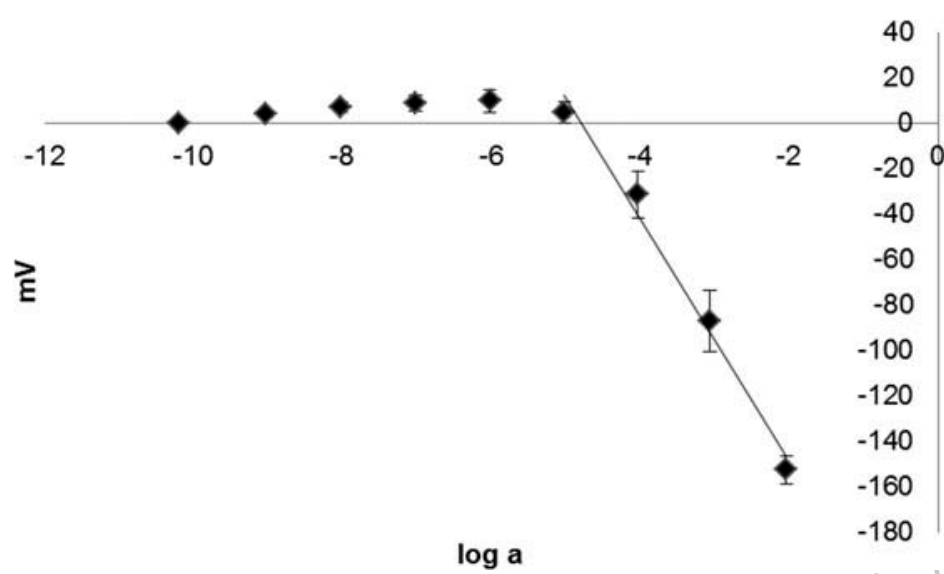

Figure 4. Sensor response to diclofenac ( $n=4$ separate electrodes).

$-53.3 \pm 3.6 \mathrm{mV} / \mathrm{dec}$, with a linear range of $3.18 \times 10^{-3} \mathrm{~g} \mathrm{~L}^{-1}$ to $3.18 \mathrm{~g} \mathrm{~L}^{-1}$. An limit of detection (LOD) of $2.90 \times \times_{\perp}^{1} 0_{\perp}^{-3} \mathrm{~g} \mathrm{~L}^{-1}$ is reported.

\subsection{Selectivity}

Selectivity testing was also carried out via titration with common anions in the Hofmeister series of lipophilicity. This is a measure of how well the electrodes perform in the presence of interferent ions, as in a real sample matrix. Figure 5 also demonstrates that in addition to providing ion exchange functionality, the IL used induces selectivity for diclofenac obviating the need for an additional ionophore, normally present in ISE membranes. This represents a further simplification of the ISE construct [20-22].

The SSM $M_{\Lambda}$ was used to determine the selectivity coefficient, $K_{i, j}^{\text {pot }}$, following IUPAC recommended methods [23] (Equation 1), where $i=$ diclofenac, and $j=$ interfering ion.

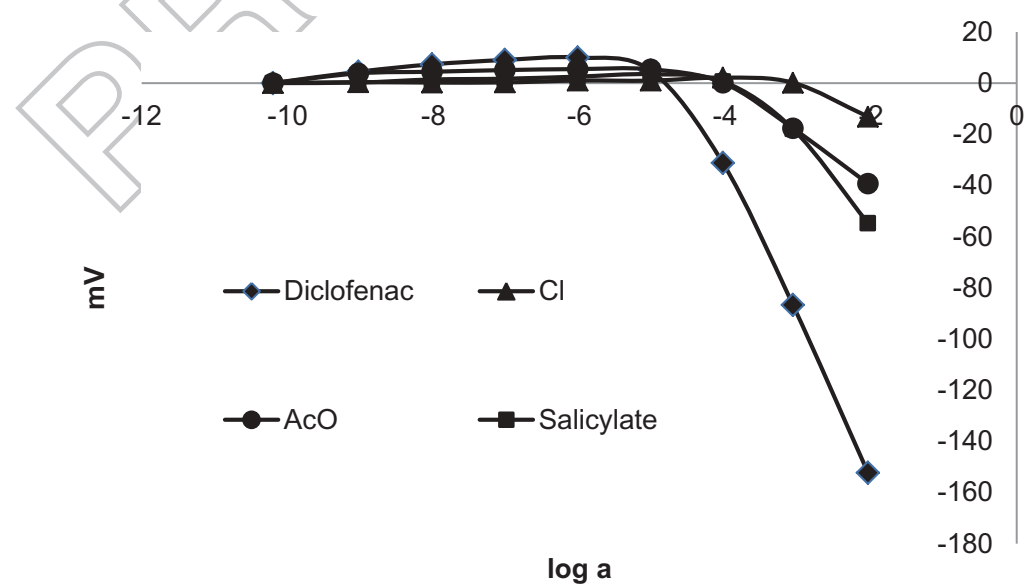

Figure 5. Response of sensors $(n=4)$ to diclofenac and some interferent anions. Some tested anions have been omitted for clarity (refer to Table 1 ). 


$$
{ }_{i . j}^{\text {pot }}=\exp \left\{\frac{E_{j}-E_{i}}{R T} z_{1} F\right\}
$$

$K_{i . j}^{\text {pot }}$ is presented as its logarithm for accessibility (Table 1). The negative values indicate the sensor's preferential detection of diclofenac over the interferent anions tested. The order of selectivity shows slight deviation from the Hofmeister (lyotropic) series of ions [24], where the response sequence is $\mathrm{F}^{-}=\mathrm{SO}_{4}{ }^{2-}<\mathrm{AcO}^{-}<\mathrm{Cl}^{-}<\mathrm{NO}_{3}{ }^{-}$. Diclofenac is expected to occur after nitrate in the series. The sensors are shown to be least selective to chloride, a prominent anion in both environmental and biological systems. Selectivity for diclofenac over other small organic molecules with carboxylate functionality, represented by acetate and salicylate, is also practically relevant, along with the analgesics ibuprofen and aspirin (Table 1). The sensors exhibit a negligible response to ascorbic acid.

A summary of electrode data is presented (Table 2) in comparison with published diclofenac-selective electrochemical sensors. The proposed sensors compare well to existing potentiometric sensors in terms of linear range and lower detection limits, with good selectivity observed. It should be noted that selectivity coefficients are not calculable for voltammetric methods. By nature, voltammetric studies exhibit low detection limits and linear ranges, where potentiometric sensors tend to utilise a simpler format and are more appropriate for longer term monitoring applications.

\subsection{Reversibility study}

It is essential that a sensor can quickly detect changes in diclofenac concentration, with consistent values. Reversibility studies were carried out by shifting between different diclofenac concentrations, and recording the signal.

Table 1. Selectivity coefficients for interferent molecules.

\begin{tabular}{lc}
\hline Interferent molecules & $\log K_{i, j}^{\text {pot }}$ \\
\hline $\mathrm{Cl}^{-}$ & -3.85 \\
$\mathrm{NO}_{3}{ }^{-}$ & -3.45 \\
$\mathrm{SO}_{4}{ }^{2-}$ & -3.46 \\
$\mathrm{~F}^{-}$ & -3.54 \\
$\mathrm{AcO}^{-}$ & -2.97 \\
$\mathrm{Salicylate}^{-}$ & -2.46 \\
$\mathrm{Br}^{-}$ & -3.95 \\
Paracetamol & -1.99 \\
Aspirin & -2.51 \\
Ibuprofen & -2.04 \\
\hline
\end{tabular}

Table 2. Comparison with literature values.

\begin{tabular}{|c|c|c|c|c|c|}
\hline Method & $\begin{array}{l}\text { Limit of detection } \\
\quad\left(\text { LOD) }\left(\mathrm{g} \mathrm{L}^{-1}\right)\right.\end{array}$ & Linear range $\left(\mathrm{g} \mathrm{L}^{-1}\right)$ & $\begin{array}{l}\text { Slope (mV/ } \\
\text { dec) }\end{array}$ & $\log K_{\mathrm{dfc} . \mathrm{Cl}}^{\mathrm{pot}}$ & Reference \\
\hline Ion-selective electrode & $6.36 \times 10^{-2}$ & $9.86 \times 10^{-2}$, to 3.49 & $48.2 \pm 1.7$ & $<2$ & [13] \\
\hline \multirow[t]{3}{*}{ (potentiometric) } & $3.20 \times 10^{-3}$ & 0.16 to 15.91 & $38.0 \pm 1.2$ & $\widehat{-5}$ & [11] \\
\hline & $10.20 \widehat{\times 1} 10^{-\hat{3}}$ & $1.59 \times 10^{-2}$ to 3.18 & $58.1 \pm 0.8$ & +0.36 & [25] \\
\hline & $2.90 \times 10^{-\hat{3}}$ & $3.20 \times 10^{-3}$ to 3.18 & $-53.3 \pm 3.6$ & -3.85 & This paper \\
\hline Differential pulse & $6.0 \times 10^{-5}$ & $1.60 \times 10^{-4}$ ㄴ $9.50 \times 10^{-2}$ & - & - & [26] \\
\hline voltammetry & $1.27 \times 10^{-5}$ & $5.70 \times 10^{1}$, to $37.85 \times 10^{-4}$ & - & - & {$[27]$} \\
\hline Square wave voltammetry & $1.97 \times 10^{-\frac{1}{6}}$ & $3.18 \times 10^{-6}$ to $3.20 \times 10^{-4}$ & - & - & {$[28]$} \\
\hline HPLC & $7.27 \times 10^{-\frac{1}{\lambda}}$ & $1.24 \times 10^{-4}$, to $6.0 \times 10^{-4}$ & - & - & [29] \\
\hline
\end{tabular}




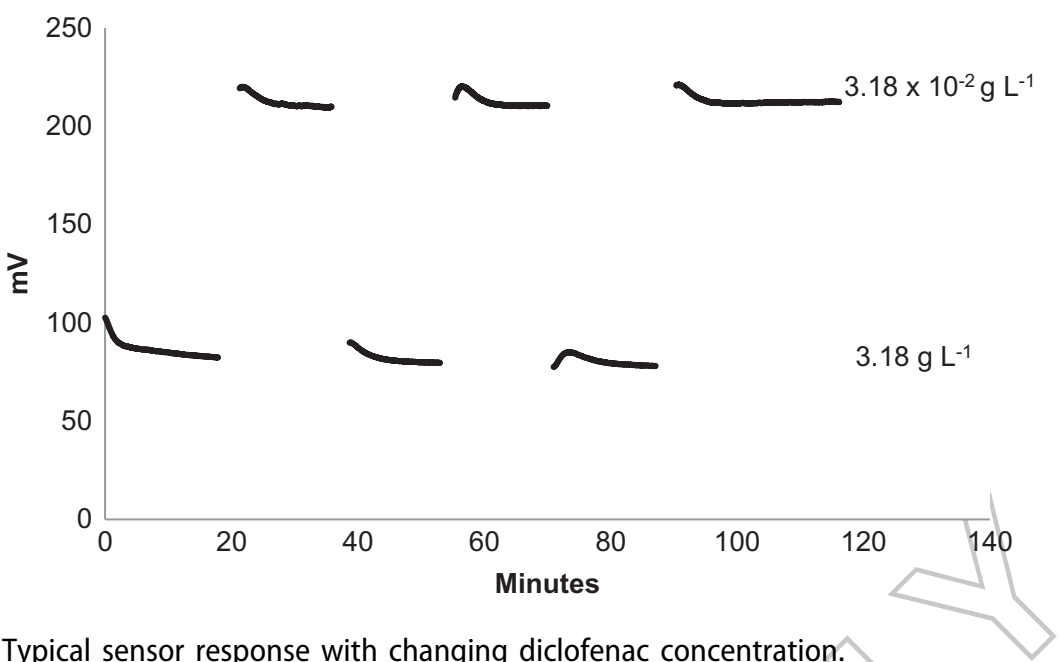

Figure 6. Typical sensor response with changing diclofenac concentration.

Table 3. Reversibility of signal response $(n=4)$.

\begin{tabular}{lcc}
\hline Concentration $\left(\mathrm{g} \mathrm{L}^{-1}\right)$ & Response $(\mathrm{mV})$ & \% RSD \\
\hline 3.18 & $83.0 \pm 2.9$ & 3.45 \\
$3.18 \times 10_{\curlywedge}^{-2}$ & $212.7 \pm 0.3$ & 0.14 \\
\hline
\end{tabular}

The sensors were switched between two diclofenac solutions ( 3.18 and $3.18 \times 10_{\Lambda}^{-2} \mathrm{~g} \mathrm{~L}^{-1}$; Figure 6). The sensors exhibit excellent signal reversibility between different concentrations of diclofenac (Table 3), with $a<15$ s response time.

For alternate concentrations of 3.18 and $3.18 \times 10_{\curlywedge}^{-2} \mathrm{~g} \mathrm{~L}^{-1}$ diclofenac, relative 160 standard deviations (RSD) of $<5 \%$ were observed, indicating precise measurements. This suggests that diclofenac ions are not immobilised permanently in the membrane, even at relatively high concentrations, and exchange with sample solutions occurs on a practical timescale. The high degree of precision demonstrates the sensors' functionality over a wide range of concentrations.

\subsection{Real sample assay}

The sensors were used to determine diclofenac in both a topical pharmaceutical gel and spiked spring water (Table 4) to assess electrode function in both pharmaceutical and environmental sample matrices. A standard addition method was employed to negate

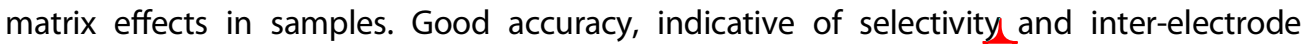
precision were observed compared to those in literature. The favourable selectivity demonstrated in the samples is in accordance with calculated selectivity coefficients (Table 1).

Table 4. Diclofenac determination in samples (RSD $<3.5 \%$ for $n=4$ ).

\begin{tabular}{|c|c|c|c|c|}
\hline Sample & Nominal content & Content determined by electrode & Recovery (\%) & Reference \\
\hline Diclac $^{\circledR}$ gel & $1 \% \mathrm{w} / \mathrm{w}$ & $0.99 \pm 0.02 \% \mathrm{w} / \mathrm{w}$ & 99.0 & This paper \\
\hline Spring water & 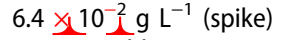 & $6.21 \times \times_{\lambda} 10_{\lambda}^{-2} \pm 2.40 \times x_{\lambda} 10_{\Lambda}^{-3} \mathrm{~g} \mathrm{~L}^{-}$ & 97.0 & \\
\hline Dicloran ${ }^{\circledast}$ tablet & $100 \mathrm{mg} / \mathrm{tablet}$ & $\frac{101.20}{20} \pm 1.60 \mathrm{mg}$ & 101.2 & [11] \\
\hline Tablet sample & $6.4 \times{ }_{2} 10_{\curlywedge}^{-3} \mathrm{~g} \mathrm{~L}^{-1}$ & 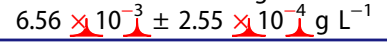 & 103.0 & [26] \\
\hline
\end{tabular}




\section{Conclusions}

This paper presents a novel, solid state membrane sensor for use in diclofenac determination. The sensors are compact and can be produced at a low cost. Given the favourable selectivity and good reversibility, both environmental and pharmaceutical applications are envisaged for the sensor.

\section{Acknowledgement}

The authors acknowledge funding from DIT's Fiosraigh scholarship.

\section{Disclosure statement}

AQ7 No potential conflict of interest was reported by the authors.

\section{Funding}

The authors acknowledge funding from DIT's Fiosraigh scholarship.

\section{References}

[1] B. Petrie, R. Barden and B. Kasprzyk-Hordern, Water Res. 72, 3 (2014).

[2] S.D. Richardson and T.A. Ternes, Anal. Chem. 83, 4616 (2011). doi:10.1021/ac200915r.

[3] S. Shultz, H.S. Baral, S. Charman, A.A. Cunningham, D. Das, G.R. Ghalsasi, M.S. Goudar, R.E. Green, A. Jones, P. Nighot, D.J. Pain and V. Prakash, Proc. R. Soc. London B Biol. Sci. 271, S458 (2004). doi:10.1098/rsbl.2004.0223.

[4] J.L. Oaks, M. Gilbert, M.Z. Virani, R.T. Watson, C.U. Meteyer, B.A. Rideout, H.L. Shivaprasad, S. Ahmed, M.J. Iqbal Chaudhry, M. Arshad, S. Mahmood, A. Ali and A. Ahmed Khan, Nature 427, 630 (2004). doi:10.1038/nature02317.

[5] B. Schazmann and D. Diamond, New J. Chem. 31, 587 (2007). doi:10.1039/B702841P.

[6] B. Schazmann, S. O'malley, K. Nolan and D. Diamond, Supramol. Chem. 18, 515 (2006). doi:10.1080/10610270600837173.

[7] A. Radu, T. Radu, C. McGraw, P. Dillingham, S. Anastasova-Ivanova and D. Diamond, J. Serbian Chem. Soc. 78, 1729 (2013). doi:10.2298/JSC130829098R.

[8] C. Fay, S. Anastova, C. Slater, S. Buda, S. Teodora, R. Shepherd, B. Corcoran, N.E. O'Connor, G.G. Wallace, A. Radu and D. Diamond, IEEE Sens. J. 11, 2374 (2011). doi:10.1109/JSEN.2011.2122331.

[9] S. Anastasova-Ivanova, U. Mattinen, A. Radu, J. Bobacka, A. Lewenstam, J. Migdalski, M. Danielewski and D. Diamond, Sens. Actuators. B. Chem 146, 199 (2010). doi:10.1016/j.snb.2010.02.044.

[10] Z.A. Kormosh, I.P. Hunka and Y.R. Bazel, J. Anal. Chem. 64, 853 (2009). doi:10.1134/ S1061934809080140.

[11] Z. Kormosh, I. Hunka, Y. Bazel, A. Laganovsky, I. Mazurenko and N. Kormosh, Cent. Eur. J. Chem. 5, 813 (2007).

[12] Z. Kormosh, I. Hunka and Y. Bazel, Chin. Chem. Lett 18, 1103 (2007). doi:10.1016/j.cclet.2007.07.007.

[13] M.C. Oliveira, E.H. Bindewald, L.H. Marcolino and M.F. Bergamini, J. Electroanal. Chem. 732, 11 (2014). doi:10.1016/j.jelechem.2014.08.006.

[14] D. Vlascici, D. Modra, V. Ostafe, L. Nica and E. Fagadar-Cosma, In Proc. 1st WSEAS Int. Conf. Nanotechnol. (World Scientific and Engineering Academy and Society (WSEAS), Stevens Point, Wisconsin, USA, 2009), pp. 52.

[15] M. Galiński, A. Lewandowski and I. Stepniak, Electrochim. Acta 51, 5567 (2006). doi:10.1016/j. electacta.2006.03.016. 
[16] D.V. Chernyshov, M.G. Khrenova, I.V. Pletnev and N.V. Shvedene, Mendeleev Commun. 18, 88 (2008). doi:10.1016/j.mencom.2008.03.012.

[17] D. Wei and A. Ivaska, Anal. Chim. Acta 607, 126 (2008). doi:10.1016/j.aca.2007.12.011.

[18] M. Elyasi, M.A. Khalilzadeh and H. Karimi-Maleh, Food. Chem 141, 4311 (2013). doi:10.1016/j. foodchem.2013.07.020.

[19] J. Bobacka, Anal. Chem. 71, 4932 (1999). doi:10.1021/ac990497z.

[20] L. Mendecki, N. Callan, M. Ahern, B. Schazmann and A. Radu, Sensors (Basel) 16, 1106 (2016). 220 doi:10.3390/s16071106.

[21] L. Mendecki, X. Chen, N. Callan, D.F. Thompson, B. Schazmann, S. Granados-Focil and A. Radu, Anal. Chem. 88, 4311 (2016). doi:10.1021/acs.analchem.5b04461.

[22] B. Schazmann and A. Radu, Int. Appl. No.PCT/EP2015/070658 (2016).

[23] IUPAC, Pure Appl. Chem. 51, 1913 (1979).

[24] J. Lyklema, Chem. Phys. Lett. 467, 217 (2009). doi:10.1016/j.cplett.2008.11.013.

[25] A.O. Santini, H.R. Pezza and L. Pezza, Talanta 68, 636 (2006). doi:10.1016/j.talanta.2005.05.016.

[26] A.A. Ensafi, M. Izadi and H. Karimi-Maleh, Ionics (Kiel) 19, 137 (2013). doi:10.1007/s11581012-0705-0.

[27] M. Arvand, T.M. Gholizadeh and M.A. Zanjanchi, Mater. Sci. Eng. C 32, 1682 (2012). 230 doi:10.1016/j.msec.2012.04.066.

[28] R.N. Goyal, S. Chatterjee and B. Agrawal, Sens. Actuators. B. Chem. 145, 743 (2010). doi:10.1016/j.snb.2010.01.038.

[29] M.A. Castillo and L. Bruzzone, Anal. Sci. 22, 431 (2006). doi:10.2116/analsci.22.431.
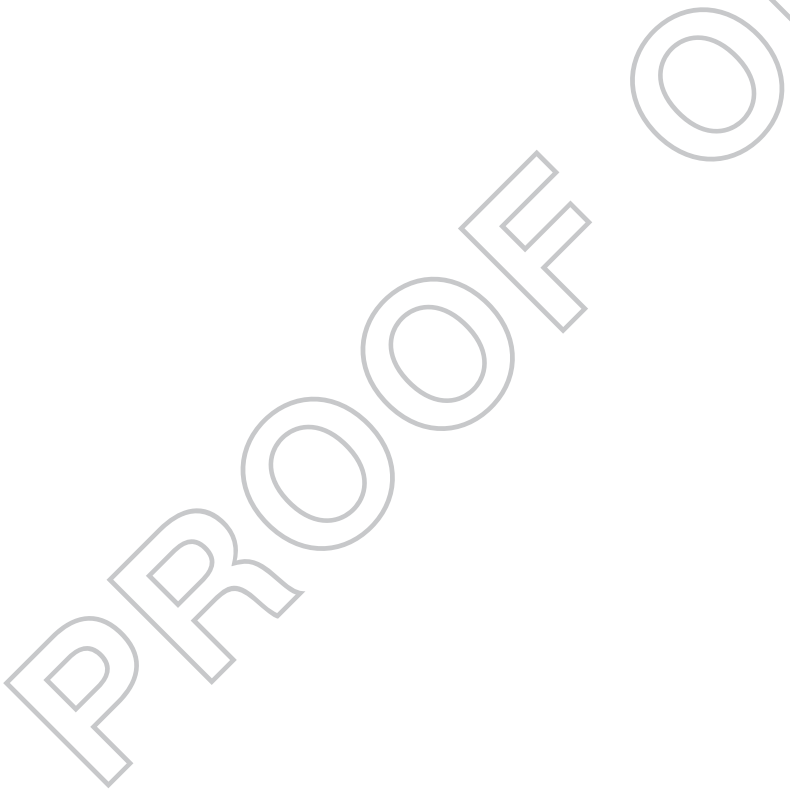